\title{
Transplacental induction of fatty acid oxidation in term fetal pigs by the peroxisome proliferator-activated receptor alpha agonist clofibrate
}

\author{
Xi Lin", Sheila Jacobi and Jack Odle
}

\begin{abstract}
Background: To induce peroxisomal proliferator-activated receptor a (PPARa) expression and increase milk fat utilization in pigs at birth, the effect of maternal feeding of the PPARa agonist, clofibrate (2-(4-chlorophenoxy)-2-methyl-propanoic acid, ethyl ester), on fatty acid oxidation was examined at full-term delivery $(0 \mathrm{~h})$ and $24 \mathrm{~h}$ after delivery in this study. Each group of pigs $(n=10)$ was delivered from pregnant sows fed a commercial diet with or without $0.8 \%$ clofibrate for the last $7 \mathrm{~d}$ of gestation. Blood samples were collected from the utero-ovarian artery of the sows and the umbilical cords of the pigs as they were removed from the sows by C-section on day 113 of gestation.

Results: HPLC analysis identified that clofibric acid was present in the plasma of the clofibrate-fed sow $(\sim 4.2 \mu \mathrm{g} / \mathrm{mL})$ and its offspring $(\sim 1.5 \mu \mathrm{g} / \mathrm{mL})$. Furthermore, the maternal-fed clofibrate had no impact on the liver weight of the pigs at $0 \mathrm{~h}$ and $24 \mathrm{~h}$, but hepatic fatty acid oxidation examined in fresh homogenates showed that clofibrate increased $(P<0.01){ }^{14} \mathrm{C}$-accumulation in $\mathrm{CO}_{2}$ and acid soluble products 2.9 -fold from $\left[1-{ }^{14} \mathrm{C}\right]$-oleic acid and 1.6 -fold from $\left[1-{ }^{14} \mathrm{C}\right]$-lignoceric acid respectively. Correspondingly, clofibrate increased fetal hepatic carnitine palmitoyltransferase (CPT) and acyl-CoA oxidase (ACO) activities by $36 \%$ and $42 \%$ over controls $(P<0.036)$. The mRNA abundance of CPT I was 20 -fold higher in pigs exposed to clofibrate $(P<0.0001)$ but no differences were detected for ACO and PPARa mRNA between the two groups.
\end{abstract}

Conclusion: These data demonstrate that dietary clofibrate is absorbed by the sow, crosses the placental membrane, and enters fetal circulation to induce hepatic fatty acid oxidation by increasing the CPT and ACO activities of the newborn.

Keywords: Clofibrate, Fatty acid oxidation, Pigs, Placenta transfer

\section{Background}

High postnatal mortality has been recognized as a critical problem by the modern swine industry since the 1990's. Although genetic improvement has increased the number of pigs born alive per litter, the death rate of newborn pigs during the postnatal period has increased slightly in recent years, from $13.2 \%$ in 2006 [1] to $14.8 \%$ in 2010 [2]. The epidemiology of postnatal mortality is complex, but data clearly show that inadequate energy (starvation) ranks among the leading causes, especially

\footnotetext{
*Correspondence: lin_xi@ncsu.edu

Laboratory of Developmental Nutrition, Department of Animal Sciences, North Carolina State University, Box 7621, Raleigh, NC 27695, USA
}

in the first three days after birth. The immediate postnatal period poses the greatest challenge to the energy balance of neonates, which must rapidly switch from carbohydrates supplied by the mother in utero [3] to predominantly lipids supplied via milk. Sow milk fat concentration is about $6 \%$ at birth and increases to $10 \%$ within $24 \mathrm{~h}$. This is $67-70 \%$ higher than human colostrum $(3.5-6 \%)$ and constitutes up to $60 \%$ of the energy in the milk, indicating that the milk fat is the primary energy source for newborn pigs after birth. Thus, it is critical for newborn pigs to use milk fat efficiently at birth to survive. However, results from previous studies show that over $85 \%$ of the fatty acids taken up by newborn pig hepatocytes are re-esterified 
but not oxidized [4]. In addition, $80 \%$ of the acetyl-CoA produced from fatty acid $\beta$-oxidation in mitochondria and/or peroxisomes is converted to acetate rather than ketone bodies [5]. These results indicate that newborn pigs have a limited capacity to oxidize milk fat for energy production at birth.

Hepatic fatty acid $\beta$-oxidation pathways are controlled mainly by the key enzymes carnitine palmitoyltransferase I (CPT I) in mitochondria and acyl-CoA oxidase (ACO) in peroxisomes. The activities of these key enzymes are transcriptionally regulated by the peroxisomal proliferatoractivated receptor $\alpha$ (PPAR $\alpha$; [6]). This central transcription factor, PPAR $\alpha$, can be activated by its natural ligands such as eicosanoids and long-chain fatty acids or a host of pharmaceutical agonists including fibrates, a class of amphipathic carboxylic acids. Clofibrate, a potent pharmaceutical PPAR $\alpha$ agonist of the fibrate class, stimulates hepatic mitochondrial and peroxisomal fatty acid $\beta$-oxidation by inducing PPAR $\alpha$ target genes such as CPT $\mathrm{I}$ and $\mathrm{ACO}$ mRNA expressions and protein activities. The induction of CPT I and ACO by clofibrate via activation of PPAR $\alpha$ has been documented in rodent species [7], laying hens [8], dairy cows [9] and pigs [10,11]. Data from our previous studies showed that the total CPT and ACO activity increase 2- and 3-fold respectively in the livers of pigs fed clofibrate for 2 weeks. Feeding clofibrate also increases hepatic peroxisomal and mitochondrial $\beta$-oxidation of $\left[1-{ }^{14} \mathrm{C}\right]$-palmitate by $60 \%$ and $186 \%$, respectively, in addition to the increased CPT I and ACO specific activities [10]. Moreover, the increase in hepatic fatty acid oxidation is not accompanied by a significant hyperplasia or hepatomegaly [12] as observed in rodent species. These results indicate that the fatty acid oxidative capacity of pigs could be promoted via induction of PPAR $\alpha$ without substantial peroxisome proliferation.

Recently we have demonstrated that supplementation of clofibrate could improve in vivo fatty acid oxidation in neonatal pigs [13]. However, increasing the fatty acid oxidative capacity of pigs at birth appears to be the key to improving energy utilization and increasing survivability. The question is whether the activities of CPT I and ACO can be increased by activation of PPAR $\alpha$ prenatally. Whether PPAR $\alpha$ agonist can be delivered to the newborn pigs via maternal diet is not known. Research concerning the impact of maternal feeding of clofibrate during pregnancy on fetal fatty acid oxidative capacity at birth or/and development after birth is very limited. Maternal dietary clofibrate induced peroxisomal proliferation in the liver and intestine tissues, and induced enterocyte peroxisomal catalase and peroxisomal bifunctional enzyme activities of fetuses in rats [14]. Maternal clofibrate also amplified fetal liver endoplasmic reticulum and peroxisomes, and increased the concentrations of peroxisomal membrane protein 70 , the specific activity of dihydroxyacetone phosphate acyltransferase and catalase in the livers of fetal mice [15]. The relative expression of cytochrome P4504A mRNA was increased in the maternal liver and fetal rat tissues [16]. Furthermore, the increase in relative mRNA of ACO, CPT I, medium- and long-chain acyl-CoA dehydrogenases in the liver were also observed in fetal rats from the clofibrate-treated maternal rats [17]. These findings demonstrate that clofibrate is capable of crossing the placenta and increasing peroxisome proliferation and modulating specific gene expression. Therefore, we hypothesize that similar placenta transfer may occur in pigs, although the physiology of extra embryonic membrane attachment in swine are different from rodents and other species. The placental transfer of clofibrate has not been studied directly by measuring clofibrate in the circulation system of the pregnant animals and their fetuses, and the effect of the induction in enzyme activities and mRNA expression on fatty acid oxidative capacity is not known.

To test our hypothesis, we investigated the effect of maternal supplementation of PPAR $\alpha$ agonist clofibrate on the development of oxidative capacity of newborn pigs at birth and $24 \mathrm{~h}$ after birth. We confirmed that PPAR $\alpha$ agonist clofibrate transfers across porcine placental tissues by measuring maternal and fetal plasma clofibrate concentrations and increases hepatic oxidative capacity by measuring hepatic fatty acid oxidation in the newborns using $\left[1-{ }^{14} \mathrm{C}\right]$-fatty acid substrates.

\section{Methods}

\section{Animals, treatments and sampling}

All procedures were approved by the Institutional Animal Care and Use Committee of North Carolina State University (IACUC number: 07-001-A). Twenty newborn pigs from either control $(\mathrm{n}=10$, body weight $=1.37 \pm 0.047 \mathrm{~kg})$ or clofibrate fed ( $\mathrm{n}=10$, body weight $=1.20 \pm 0.024 \mathrm{~kg}$ ) sows were used in this study. Pregnant multiparous crossbred sows were housed at the North Carolina State University Swine Education Unit and were fed a standard gestation diet $(3,265 \mathrm{Kcal} \mathrm{ME} / \mathrm{kg})$ with or without supplementation of $0.8 \%$ colfibrate $(\mathrm{w} / \mathrm{w})$ from day 105 of gestation until day 113. The clofibrate was diluted into $10 \mathrm{~mL}$ of ethanol and pre-mixed with $\sim 50 \mathrm{~g}$ of feed each day. Sows were fed the premixes (clofibrate or vehicle) together with $\sim 1 / 3$ of their daily feed allotment first, to ensure complete consumption, and then the remaining $2 / 3$ allotment was provided. The sows were given $1.75 \mathrm{~kg}$ diets per day in total and water was supplied ad libitum. Term fetuses were delivered by caesarian section on d 113 of gestation and plasma was collected simultaneously from the utero-ovarian artery of swine and from the umbilical vein of each fetal pig.

All newborn pigs were weighed and euthanized by AVMA-approved electrocution at time 0 (term fetus, 
$\mathrm{n}=6)$ or $24 \mathrm{~h}(\mathrm{n}=4)$ after delivery. The pigs sampled at $24 \mathrm{~h}$ were housed at $35^{\circ} \mathrm{C}$ in a specialized nursery facility [18] and remained un-fed. Liver samples were immediately homogenized in a buffer $(220 \mathrm{mmol} / \mathrm{L}$ mannitol, $70 \mathrm{mmol} / \mathrm{L}$ sucrose, $2 \mathrm{mmol} / \mathrm{L}$ HEPES, and $0.1 \mathrm{mmol} / \mathrm{L}$ EDTA; pH 7.2 at $0^{\circ} \mathrm{C}$ ) using a $7 \mathrm{~mL}$ glass Pyrex hand homogenizer with 3 complete top to bottom strokes. Fatty acid oxidation in the fresh homogenate was measured immediately using $\left[1-{ }^{14} \mathrm{C}\right]$-fatty acids. Homogenate protein was determined using the biuret method [19]. Samples were also immediately frozen in liquid nitrogen and stored at $-80^{\circ} \mathrm{C}$ for enzyme and mRNA assays.

\section{Plasma assay}

Clofibrate (2-(4-Chlorophenoxy)-2-methylpropionic acid ethyl ester), clofibric acid (2-(4-chlorophenoxy)-2methylpropionic acid), 4-chlorophenylacetic acid and its metabolites in the plasma from the sows and term fetuses were extracted using solid-phase extraction (SPE) procedures as described by $\mathrm{Du}$ et al. [20]. The extraction was conducted using SPEC.C18 extraction cartridges (Ansys Technologies, CA, and USA). The clofibrate, clofibric acid, and other lipophilic components were eluted with a solvent mixture of acetonitrile : water : formic acid (79\%:20\%:1\%, v/v/v) and were analyzed using a Waters HPLC Empower system (Milford, MA. USA). The separation of clofibrate, clofibric acid, and their metabolites was performed on a BDS Hypersil C18 $(5 \mu \mathrm{m}, 150 \mathrm{~mm} \times 46 \mathrm{~mm})$ analytical column with BDS C18 $(5 \mu \mathrm{m}, 4 \mathrm{~mm} \times 3.0 \mathrm{~mm})$ guard column from Phenomenex (Torrance, CA. USA). The isocratic HPLC system was used and the pump flow rate was set at $1 \mathrm{~mL} / \mathrm{min}$. The sample injection volume was $20 \mu \mathrm{L}$ and the compounds were detected at $230 \mathrm{~nm}$ using a photodiode array detector (Waters 996).

\section{Fatty acid oxidation}

Hepatic fatty acid oxidations were measured in fresh liver homogenates from the pigs at 0 or $24 \mathrm{~h}$ without suckling after delivery using $\left[1-{ }^{14} \mathrm{C}\right]$-oleic acid $(\mathrm{C} 18: 1$, the most enriched fatty acid in pig milk) and $\left[1-{ }^{14} \mathrm{C}\right]$-lignoceric acid (C24:0, primary oxidized in peroxisomes) as substrates. The measurements followed the same procedure as described previously by Lin et al. [5]. Specifically, liver homogenates $(\sim 40 \mathrm{mg})$ were incubated in $25 \mathrm{~mL}$ Erlenmeyer flasks with a final of volume of $2 \mathrm{~mL}$ of the reaction medium with or without addition of antimycin A $(50 \mu \mathrm{mol} / \mathrm{L})$ and rotenone $(10 \mu \mathrm{mol} / \mathrm{L})$ described as previously [13] for determining peroxisomal $\beta$-oxidation by inhibition of the electron transport chain of oxidative phosphorylation. The reaction was initiated by adding $2 \mu \mathrm{mol}$ of either $\left[1-{ }^{14} \mathrm{C}\right]-\mathrm{C} 18: 1(4.2 \mathrm{MBq} / \mathrm{mmol})$ or $\left[1-{ }^{14} \mathrm{C}\right]-$ C24:0 $(1 \mathrm{MBq} / \mathrm{mmol})$ and terminated by adding $0.5 \mathrm{~mL}$
$\mathrm{HCLO}_{4}$. The ${ }^{14} \mathrm{CO}_{2}$ collected in ethanolamine and the ${ }^{14} \mathrm{C}$-acid soluble products (ASP) processed from the acid-killed medium were quantified using liquid scintillation counter (Beckman LS 6000IC. Fullerton, CA. USA). The rate of total $\beta$-oxidation and the rate of peroxisomal and mitochondrial $\beta$-oxidation were calculated as described by $\mathrm{Yu}$ et al. [11].

\section{Enzyme and mRNA analysis}

Hepatic ACO activity was determined in liver homogenates using a spectrophotofluorometric assay as described by Walusimbi-kisitu and Harrison [21] with slight modifications. The homogenates were prepared in an ice cold buffer containing $250 \mathrm{mmol} / \mathrm{L}$ sucrose, $1 \mathrm{mmol} / \mathrm{L}$ EDTA and $1 \%$ ethanol. After preparation, the homogenate $(0.6 \pm$ $0.035 \mathrm{mg}$ protein) was incubated in a dark room at $37^{\circ} \mathrm{C}$ in $0.5 \mathrm{~mL}$ (final vol.) of a medium with or without $35 \mu \mathrm{mol} / \mathrm{L}$ palmitoyl-CoA for $20 \mathrm{~min}$. The incubations were stopped by adding $2 \mathrm{~mL}$ of borate buffer $(0.1 \mathrm{~mol} / \mathrm{L}$, $\mathrm{pH}$ 10). The medium contained $60 \mathrm{mmol} / \mathrm{L}$ Tris $-\mathrm{HCl}$, $50 \mu \mathrm{mol} / \mathrm{L}$ FAD, $170 \mu \mathrm{mol} / \mathrm{L}$ CoA, $1 \mu \mathrm{mol} / \mathrm{L}$ scopoletin and $6 \%$ of BSA. $200 \mu \mathrm{L}$ of the incubated medium was transferred into a 96 well plate and measured in a BioTek reader (Synergy HT) with emission at 460 and excitation at $360 \mathrm{~nm}$ (BioTek Instruments, Inc., Winooski, VT). The standard curve was generated using $\mathrm{H}_{2} \mathrm{O}_{2}(30 \%$, w/w) and $150 \mathrm{IU}$ peroxidase under the same incubation conditions and measurements.

CPT activity was measured in liver homogenates using a radio-enzymatic method as described previously by Bremer et al. [22]. The homogenate $(65 \pm 3.8 \mathrm{mg}$ protein) was pre-incubated with $80 \mu \mathrm{mol} / \mathrm{L}$ palmitoyl-CoA in a medium containing $75 \mathrm{mmol} / \mathrm{L} \mathrm{KCl}, 50 \mathrm{mmol} / \mathrm{L}$ HEPES, $0.2 \mathrm{mmol} / \mathrm{L}$ EGTA, and $1 \%$ of fatty-acid-free BSA in the presence or absence of $2.5 \mu \mathrm{mol} / \mathrm{L}$ malonyl-CoA, and the incubation was conducted at $30^{\circ} \mathrm{C}$ in a final volume of $1 \mathrm{~mL}$ for $3 \mathrm{~min}$ [5]. The measurement of the enzyme activity was initiated with $1 \mu \mathrm{mol}$ of $\left(\mathrm{l}-\right.$ methyl $\left.^{3} \mathrm{H}\right)$-carnitine $(54 \mathrm{KBq} / \mu \mathrm{mol})$ and terminated after $6 \mathrm{~min}$ by the addition of $2 \mathrm{~mL}$ of $6 \%$ of $\mathrm{HClO}_{4}(\mathrm{vol} / \mathrm{vol})$. The radioactivity in palmitoyl-carnitine, generated during the incubation was extracted with water-saturated butanol and quantified using liquid scintillation spectrometry (Beckman LS 6000IC, Fullerton, CA. USA).

Assay of mRNA was conducted using the methods described by Lin et al. [5]. Total RNA was extracted from the liver samples using guanidine isothiocynate and phenol (TRIzol Reagent, Sigma Chemical, St. Louis, MO. USA). The extracted RNA was quantified using a NanoDrop spectrophotometer (NanoDrop Technologies, Wilmington, DE. USA), and the integrity of the RNA was confirmed using gel electrophoresis with SYBR Safe TM DNA gel stain from Invitrogen Life Technologies (Carlsbad, CA. USA). The RNA $(10 \mu \mathrm{g} / 50 \mu \mathrm{L})$ then 
was treated with TuboDNase (Ambion, Austin, TX) according to the manufacturer's instructions for removal of genomic DNA and transcribed using the iScriptTM Select cDNA Synthesis Kit provided with oligo (dT) primer mix. (Bio-Rad Laboratories, Hercules, CA). The mRNA abundance of PPAR $\alpha, \mathrm{CPT} I$ ( $\mathrm{L}$ isoform) and ACO were determined using the MyiQ Single Color Real-Time PCR Detection System (Bio-Rad Laboratories, CA. USA). The determination was performed in triplicate with primers designed from pig-specific sequences available via GenBank and ordered from Sigma Genosys (St Louis, MO, USA). Amplification efficiencies were verified to be similar for the endogenous control GAPDH and the measured genes. Reactions contained cDNA with $0.4 \mu \mathrm{mol} / \mathrm{L}$ each of reverse and forward primers. The assay conditions and data calculations were the same as described previously [5].

\section{Chemicals}

Clofibrate was purchased from Cayman Chemical Company (Ann Arbor, MI. USA). [1- $\left.{ }^{14} \mathrm{C}\right]$-oleic acid (C18:1) and $\left[1-{ }^{14} \mathrm{C}\right]$-lignoceric acid (C24:0) were purchased from American Radiolabeled Chemicals, Inc. (St. Louis, MO. USA). 2-(4-Chlorophenoxy)-2-methylpropionic acid ethyl ester, 2-(4-chlorophenoxy)-2-methylpropionic acid, 4-chlorophenylacetic acid, peroxidase and all other chemicals were obtained from Sigma-Aldrich (St. Louis, MO. USA).

\section{Statistics}

Data from fatty acid oxidation measurements were analyzed according to a split-plot design with the main plots in a completely randomized design using the SAS GLM procedure. The clofibrate effect was assigned to the main plot and pig postnatal age and fatty acid chain length effects were treated as the subplots. Least squares means \pm SEM for variables are presented in tables and figures. Data from enzyme activity and mRNA enrichment assays were analyzed as a $2 \times 2$ factorial design using the GLM procedure. Least square means for treatment (clofibrate vs. control) and the postnatal age ( 0 vs. $24 \mathrm{~h})$ effects were calculated. Differences between least squares means were determined using a Tukey test and considered significant when $P \leq 0.05$.

\section{Results}

\section{Plasma assay}

Chromatograms from HPLC analysis confirmed that clofibric acid was present in the plasma of both the clofibrate-fed sow and their newborn pigs (Figure 1). In addition to clofibric acid, a clofibrate conjugate metabolite was detected in the plasma of the clofibrate-fed sow but not in the plasma of newborn pigs. An unidentified peak after the reagent peak was observed also in the chromatogram from the plasma analysis of the clofibrate-fed sow and the peak was tiny in the plasma of newborn pigs
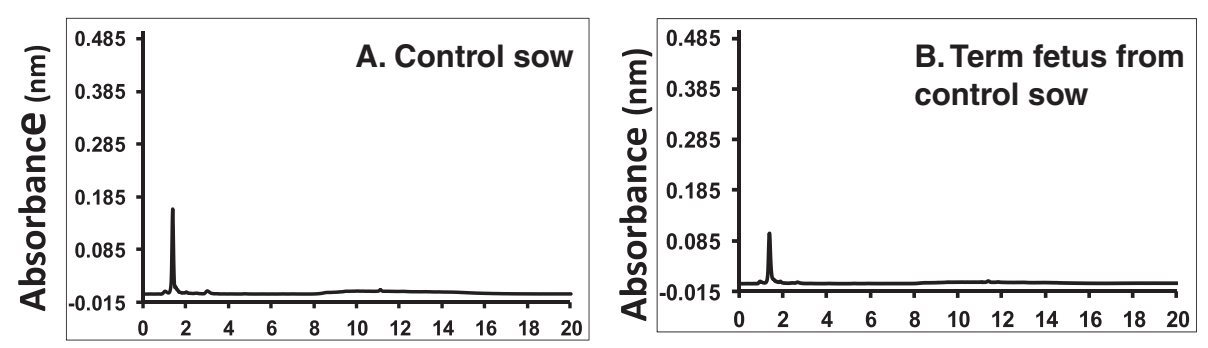

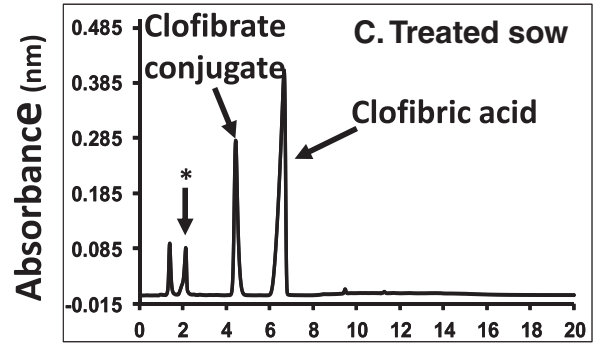

Retention time ( $\mathrm{min}$ )

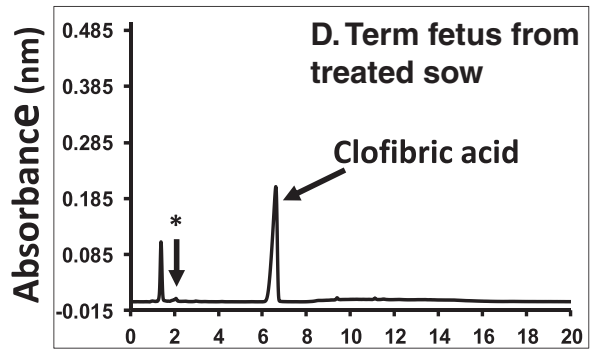

Retention time ( $\mathrm{min}$ )

Figure 1 Chromatogram of plasma samples from HPLC analysis. A. control sow, B. newborn pigs from control sow, C. clofibrate-treated sow and D. term pigs from clofibrate-treated sow. See Methods for HPLC conditions and sample injection volumes. Compounds were identified by injection of available standards purchased from Sigma-Aldrich (St. Louis, MO) under the same HPLC conditions. *Unidentified peak. 
from the clofibrate-fed sow. No peaks of clofibric acid or its metabolites were detected in the plasma of control sows or their offspring.

\section{Fatty acid oxidation}

Results from total fatty acid oxidation in vitro (Figure 2) showed that clofibrate and postnatal age significantly stimulated hepatic $\beta$-oxidation of fatty acids $(P<0.0001)$, but the stimulatory effects of clofibrate and postnatal age for $\mathrm{C} 18: 1$ oxidation were different from $\mathrm{C} 24: 0$ oxidation. The ${ }^{14} \mathrm{C}$ accumulations for $\mathrm{C} 18: 1$ on average in $\mathrm{CO}_{2}$, ASP and $\mathrm{CO}_{2}+\mathrm{ASP}(\mu \mathrm{mol} / \mathrm{h} / \mathrm{g}$ protein) measured at $0 \mathrm{~h}$ and $24 \mathrm{~h}$ were $1.9,2.2$, and 2.1 fold higher, respectively, from clofibrate exposed pigs $(2.32,13.36$ and 15.69) than control pigs $\left(1.24,6.17\right.$ and 7.41). Similarly, the ${ }^{14} \mathrm{C}$ accumulations in $\mathrm{CO}_{2}$, ASP and $\mathrm{CO}_{2}+\mathrm{ASP}(\mu \mathrm{mol} / \mathrm{h} / \mathrm{g}$ protein $)$ for C18:1 from both clofibrate treatment and control were on average $331 \%, 49 \%$ and $71 \%$ greater respectively in the livers of $24 \mathrm{~h}$ old pigs $(2.89,11.69$ and 14.58$)$ than the pigs at delivery $(0.67,7.83$ and 8.51$)$. In contrast with C18:1, the ${ }^{14} \mathrm{C}$ accumulation for $\mathrm{C} 24: 0$ on average in $\mathrm{CO}_{2}+\mathrm{ASP}(\mu \mathrm{mol} / \mathrm{h} / \mathrm{g}$ protein $)$ measured at $0 \mathrm{~h}$ and $24 \mathrm{~h}$ was 1.8 fold higher from clofibrate exposed pigs (3.32) than control pigs (1.81), but no differences were detected in the ${ }^{14} \mathrm{C}$ accumulation in $\mathrm{CO}_{2}$ and ASP (Figure 2, A \& B). In addition, the ${ }^{14} \mathrm{C}$ accumulation in $\mathrm{CO}_{2}$ from $\mathrm{C} 24: 0$ was increased on average by $61 \%$ in the livers of $24 \mathrm{~h}$ old fasted pigs compared to the pigs at delivery (0.32), but there was no postnatal age effect on the ${ }^{14} \mathrm{C}$ accumulations in ASP and $\mathrm{CO}_{2}+$ ASP (Figure 2, $B$ \& $C)$. There was no interaction between clofibrate and pig postnatal age $(P>0.05)$.

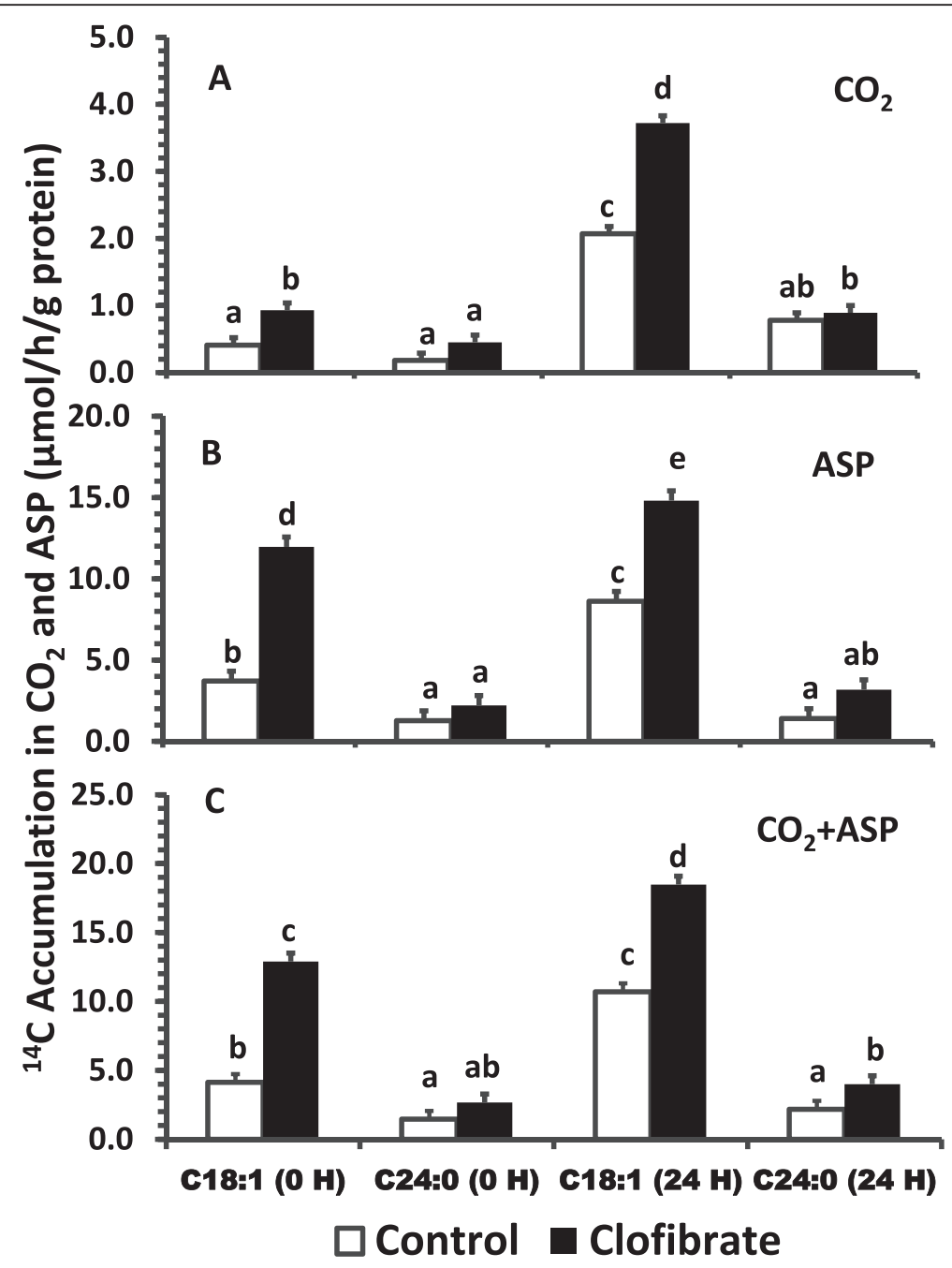

Figure 2 The effect of maternal clofibrate on total (mitochondrial and peroxisomal) fatty acid oxidation in newborn pigs at $0 \mathrm{~h}$ and $24 \mathbf{~ h}$ after delivery by $\mathbf{C}$-section. Total ${ }^{14} \mathrm{C}$ labeled carbon accumulated in $\mathrm{CO}_{2}$ (A), acid soluble products (ASP, B) and $\mathrm{CO}_{2}+\mathrm{ASP}(\mathbf{C})$. Values are least square means \pm SEM ( $n=6$ for newborn pigs at $0 \mathrm{~h}$ and $\mathrm{n}=4$ for pigs at $24 \mathrm{~h}$ ). ${ }^{\text {abcde }}$ Bars within a panel lacking a common superscript differ $(P<0.05)$. 
The mitochondrial oxidative flux of $\mathrm{C} 18: 1$ to $\mathrm{CO}_{2}$ and ASP (Figure 3, A \& B) as well as the total $\left(\mathrm{CO}_{2}+\mathrm{ASP}\right.$, Figure 3, C) was affected by the treatment of clofibrate and the postnatal age $(P<0.0001)$. The ${ }^{14} \mathrm{C}$-accumulations in $\mathrm{CO}_{2}$, ASP and $\mathrm{CO}_{2}+\mathrm{ASP}(\mu \mathrm{mol} / \mathrm{h} / \mathrm{g}$ protein) in the livers of the pigs from sow received clofibrate (2.3, 13.1 and 15.5 respectively) were on average 2.1-fold higher than that from controls (1.2, 6.2 and 7.4 respectively). Similarly, the ${ }^{14} \mathrm{C}$-accumulations in $\mathrm{CO}_{2}$, ASP and $\mathrm{CO}_{2}+\mathrm{ASP}$ also were increased on average by 3.1, 0.49 and 0.71 fold respectively in the pigs at $24 \mathrm{~h}$ after delivery $(2.9,11.7$ and 14.6) as compared to the pigs at birth $(0.7,7.8$ and 8.5$)$. However, the stimulatory effect by clofibrate on the ${ }^{14} \mathrm{C}$-accumulations in ASP and $\mathrm{CO}_{2}+$ ASP tended to attenuate with the increase in postnatal age. There was no effect of age on the ${ }^{14} \mathrm{C}$ accumulation in ASP in the pigs exposed to clofibrate (Figure $3 \mathrm{~B} ; P=0.079$ ). In contrast to C18:1, the mitochondrial oxidative flux of C24:0 to ASP and $\mathrm{CO}_{2}+\mathrm{ASP}(\mu \mathrm{mol} / \mathrm{h} / \mathrm{g}$ protein) remained similar in the livers of the pigs exposed to clofibrate $(0.3,0.83)$ and the controls $(0.4,0.9)$, although the flux to $\mathrm{CO}_{2}$ tended to be higher in the liver from the clofibrate-exposed pigs than control pigs. There was no significant change in the oxidative flux of $\mathrm{C} 24: 0$ as the postnatal age increased $(P>0.05)$.

No substantial ${ }^{14} \mathrm{C}$-accumulation in $\mathrm{CO}_{2}(<0.25, \mu \mathrm{mol} / \mathrm{h} / \mathrm{g}$ protein) was detected in peroxisomes (Figure 4, A). Clofibrate exposure and postnatal age had no impact on the negligible peroxisomal oxidative flux to $\mathrm{CO}_{2}$ from $\mathrm{C} 18: 1$, but significantly increased the flux to ASP and $\mathrm{CO}_{2}+\operatorname{ASP}(P<0.0001$; Figure $4, \mathrm{~B} \& \mathrm{C})$. The ${ }^{14} \mathrm{C}$ accumulation in the ASP and $\mathrm{CO}_{2}+\mathrm{ASP}(\mu \mathrm{mol} / \mathrm{h} / \mathrm{g}$ protein) from $\mathrm{C} 18: 1$ was on average 2 fold greater from clofibrate-treated $(5.4,5.5)$ than control $(2.7,2.7)$ pigs, and $56 \%$ higher from the $24 \mathrm{~h}$-old pigs than that from pigs at delivery $(1.3,1.7)$. In comparison to C18:1,

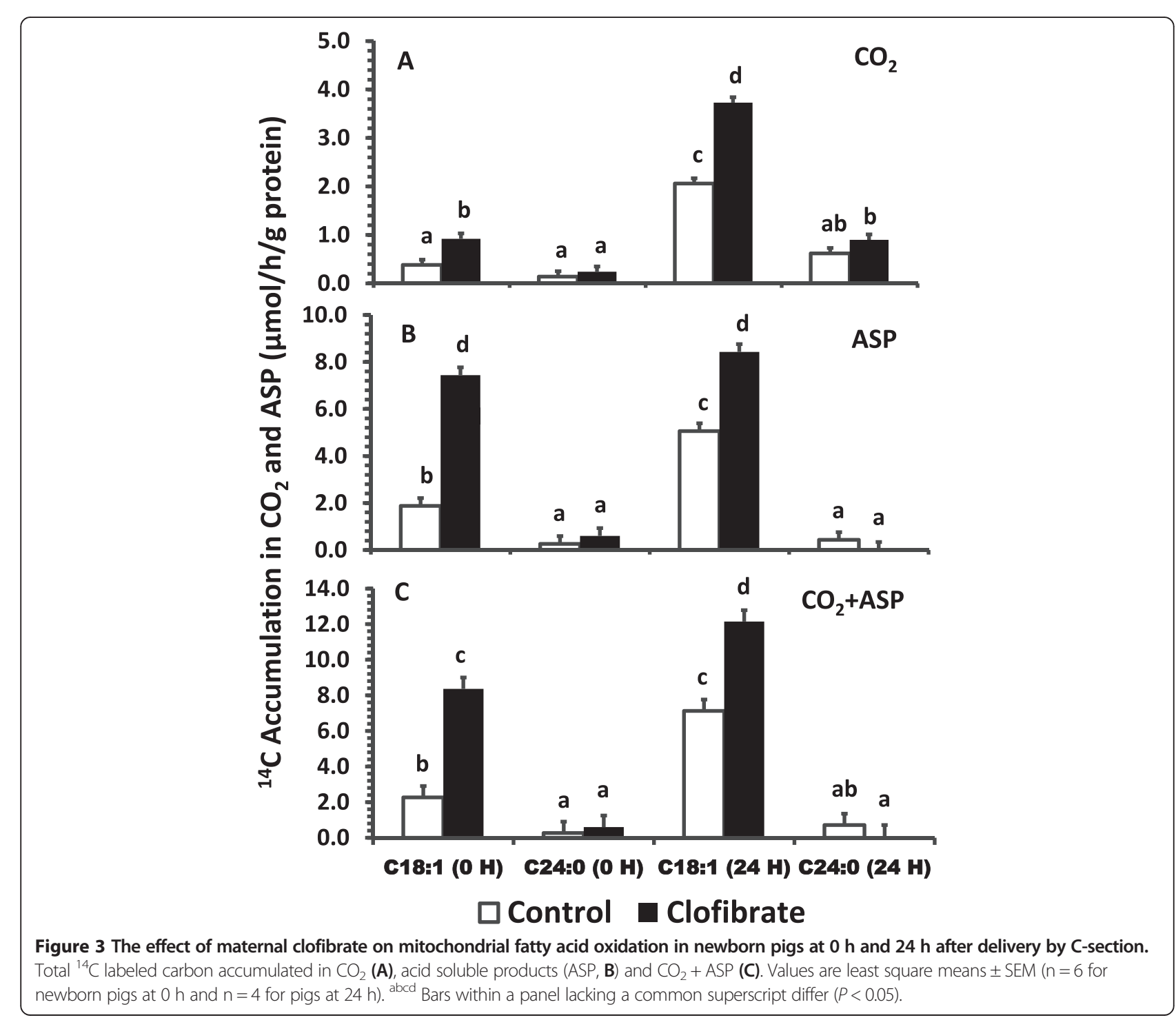




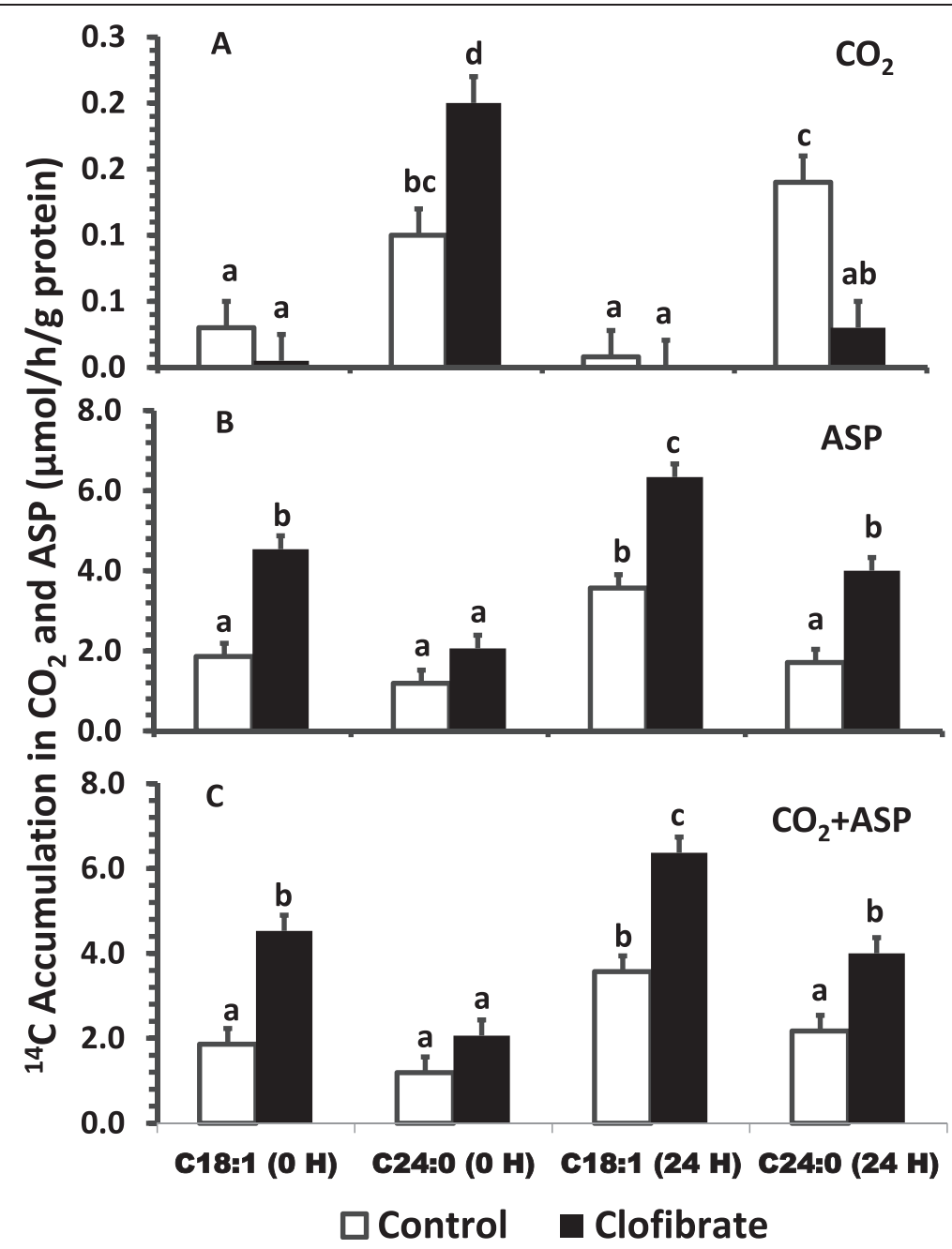

Figure 4 The effect of maternal clofibrate on peroxisomal fatty acid oxidation in newborn pigs at $0 \mathrm{~h}$ and $24 \mathrm{~h}$ after delivery by $\mathrm{C}$-section. Total ${ }^{14} \mathrm{C}$ labeled carbon accumulated in $\mathrm{CO}_{2}(\mathbf{A})$, acid soluble products (ASP, B) and $\mathrm{CO}_{2}+\mathrm{ASP}(\mathbf{C})$. Values are least square means $\pm \mathrm{SEM}(\mathrm{n}=6$ for newborn pigs at $\mathrm{O}$ h and $\mathrm{n}=4$ for pigs at $24 \mathrm{~h})$. ${ }^{\text {abcd }}$ Bars within a panel lacking a common superscript differ $(P<0.05)$.

clofibrate increased the ${ }^{14} \mathrm{C}$ accumulation from $\mathrm{C} 24: 0$ peroxisomal oxidation in $\mathrm{CO}_{2}$ in the liver of pigs at delivery but decreased in the liver of $24 \mathrm{~h}$-old pigs. Thus there was no significant difference $(P=0.93)$ in the average flux to $\mathrm{CO}_{2}(\mu \mathrm{mol} / \mathrm{h} / \mathrm{g}$ protein) between clofibrate-treated $(0.15)$ and control pigs (0.14). There were no effects of clofibrate on the ${ }^{14} \mathrm{C}$ accumulation in ASP and $\mathrm{CO}_{2}+$ ASP from C24:0 in pigs at delivery, but the ${ }^{14} \mathrm{C}$ accumulations was $84 \%$ greater from clofibrate-treated (4.0) than control in 24 h-old pigs (2.17). Postpartum age also had no influence on $\mathrm{C} 24: 0$ oxidation in pigs at delivery $(\mathrm{P}>0.05)$, but the ${ }^{14} \mathrm{C}$ accumulation in ASP and $\mathrm{CO}_{2}+\mathrm{ASP}$ was $94 \%$ higher from the clofibrate-treated pigs measured at $24 \mathrm{~h}$ (4.0) than at delivery (2.06).

Clofibrate and postnatal age had no effect on the distribution of oxidative flux $\mathrm{C} 18: 1$ and $\mathrm{C} 24: 0$ between mitochondria and peroxisome (Figure 5, P>0.05). However, the peroxisomal proportion of total fatty acid oxidation was on average 2.3 fold higher from C24:0 (85.5) than C18:1 (37.7\%).

\section{Enzyme activity and mRNA expression}

Hepatic CPT specific activity (Figure 6A) measured with and without malonyl-CoA was $69 \%$ and $43 \%$ higher, respectively, in the clofibrate-exposed pigs $(P<0.018)$. There was no change in the activities with postnatal age $(P=0.2)$. The total and inhibited enzyme activity $(\mu \mathrm{mol} /$ $\mathrm{h} / \mathrm{g}$ protein) were $31.2,52.4$ on average for the pigs at delivery and 39.3, 64 on average for the 24 h-old pigs. Hepatic ACO activity was increased by 2.3 fold in the clofibrate-exposed pigs $(P<0.036$; Figure $6 \mathrm{~B})$. The enzyme activity also increased by 1.4 fold in 24 -h-old pigs, but the increase had no influence on the degree of clofibrate stimulation $(P>0.05)$.

The relative mRNA expression of CPT I was increased by 19 -fold in liver of the clofibrate-exposed pigs $(P<0.0001)$, 


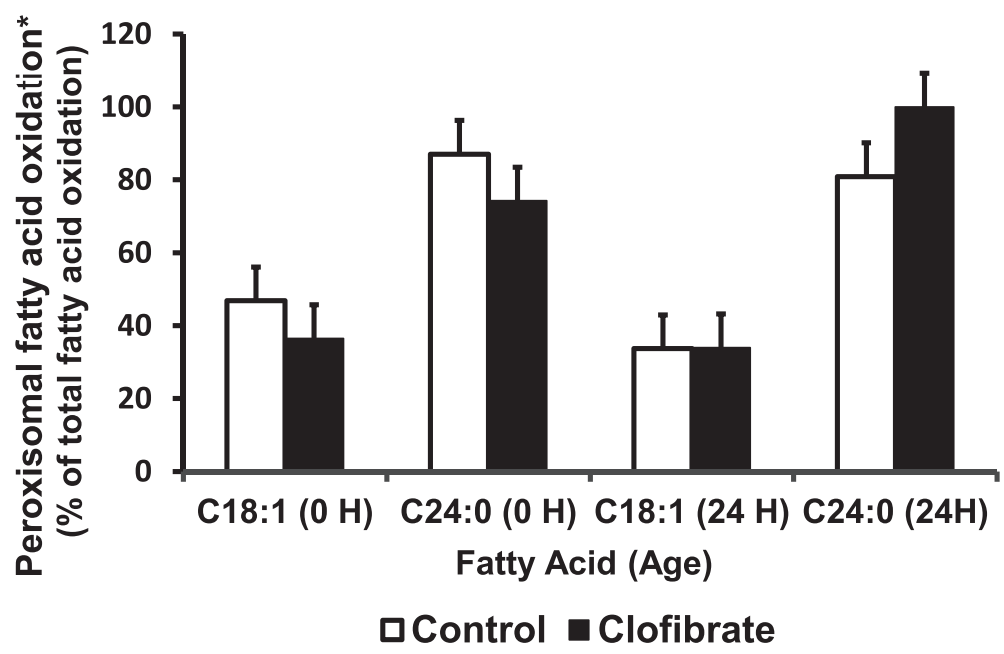

Figure 5 Percentage of peroxisomal fatty acid oxidation in total fatty acid oxidation. Values are least square means \pm SEM $(n=6$ for newborn pigs at $0 \mathrm{~h}$ and $\mathrm{n}=4$ for pigs at $24 \mathrm{~h}$ ). . Significantly different from fatty acid $(P<0.05)$.
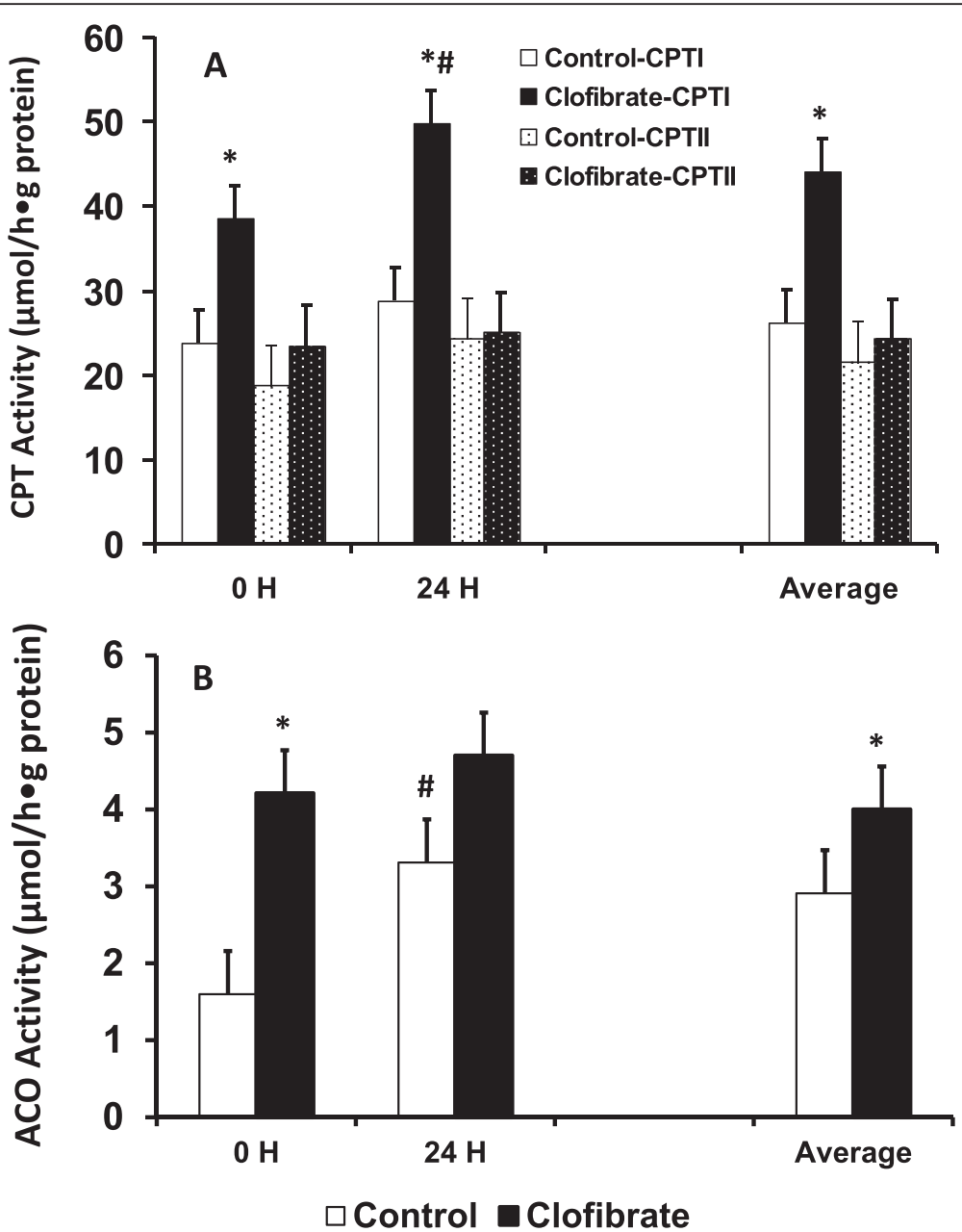

Figure $\mathbf{6}$ The effect of maternal clofibrate on enzyme specific activity in newborn pigs at birth and $\mathbf{2 4} \mathrm{h}$ after delivery by C-section. Hepatic activity of carnitine palmitoyltransferase (CPT, A) and acyl-CoA oxidase (ACO, B). Values are least square means \pm SEM ( $n=6$ for pigs at $0 \mathrm{~h}$ and $\mathrm{n}=4$ for pigs at $24 \mathrm{~h}$ ). "Significantly different from clofibrate and \# significantly different from postnatal age $(P<0.05)$. 
but no differences were detected for the relative mRNA abundance of either ACO or PPAR $\alpha(P>0.05$, Figure 7$)$.

\section{Discussion}

Previous research in rodents has shown peroxisome proliferation was observed in the liver of fetuses over 13 days and/or newborns from clofibrate treated dams during gestation $[15,23]$. The peroxisomal membrane protein 70 and the marker enzymes dihydroxyacetone phosphate acyltransferase and catalase specific activities were significantly increased in the fetal liver of mice at $19 \mathrm{~d}$ gestation [15]; indirectly suggesting that clofibrate and/or its metabolites could cross the placenta barrier to enter the circulation system of the fetus in rodent species. However, there was no direct evidence to demonstrate if clofibrate, clofibrate metabolites, or both actually cross the placental barrier. Additionally, the morphology and function of placenta vary greatly among mammals [24]. The type of placenta in swine has been described as a diffuse, folded, and epitheliochorial placenta type that is different from that of rats, which has a discoidal, labyrinthine, and hemotrichorial placenta type [25]. Considering the disparity between the morphology and mechanisms for an extra embryonic membrane attachment in swine, the placental transfer of clofibrate could be different from the rodent species. The aim of this study is to determine if clofibrate or its metabolites traverse porcine placental tissues to evaluate the effect of clofibrate on lipid metabolism in the offspring of pregnant swine fed clofibrate. Our result clearly established that clofibrate is absorbed and hydrolyzed into clofibric acid, and the clofibric acid crosses the porcine placenta with no chemical or structural modifications. The results are also in line with the previous observation that the biofunctional activity of clofibrate is due to clofibric acid [26]. In addition of the analytical results from plasma analyses,

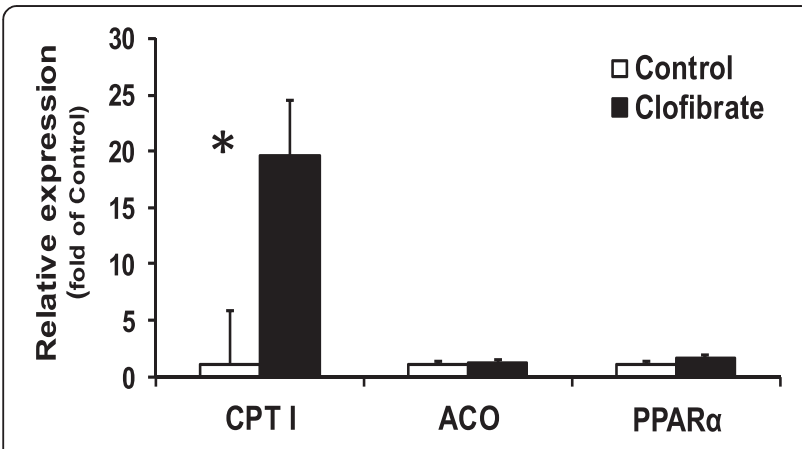

Figure 7 The effect of maternal clofibrate on mRNA expression in newborn pigs at $0 \mathrm{~h}$. mRNA expression was performed by qtPCR in duplicates. Values (fold of control) are least square means $\pm \operatorname{SEM}(n=6)$. ${ }^{*}$ Significantly different from clofibrate $(P<0.05)$. the in vitro metabolism measurements strongly support that clofibric acid delivered via the maternal diet entered fetal circulation and induced fetal hepatic fatty acid oxidation. Feeding clofibrate to neonatal pigs for 14 days and to young pigs for 28 days caused a mild increase in the liver weight as a percentage of body weight $(3.3 \%,[11] ; 3.8 \%,[27])$. The relative weight of the liver ( $\mathrm{g} / \mathrm{kg}$ body weight) measured in this study showed no difference between the pigs from the clofibrate treated group $(26.9 \pm 0.09)$ and control group $(27.9 \pm 0.15)$, suggesting that exposure to the pharmacological PPAR $\alpha$ agonist clofibrate by sows for 9 days during late pregnancy would not cause a morphological change in the liver of the offspring. Although we did not perform a histological examination, clofibrate has no substantial effect on the peroxisome proliferation in this species at the ages of 7 days and 8 weeks [28]. This is similar to humans but significantly different from the rodent species in which activation of PPAR $\alpha$ by clofibrate initiates hepatocyte proliferation and induces the well-known hepatocellular carcinoma $[29,30]$.

Evidence from rodent species demonstrated that maternal supplementation of clofibrate orally or by injection stimulates peroxisomal proliferation, decreases oxygen uptake, and alters lipid metabolism in the liver and intestine of fetuses or neonates. Maternal clofibrate induces cytochrome P4504A mRNA expression [16] and increases $\mathrm{ACO}$ and catalase specific activities in the fetal liver and kidneys [31]. Recently, the high relative mRNA expression of PPAR $\alpha$ target genes ACO, CPT I, medium- and long-chain acyl-CoA dehydrogenases were observed also in the liver of fetuses from pregnant rats fed with clofibrate and oxidized fat [17]. However, as PPAR $\alpha$ is a crucial regulator of lipid metabolism, the role of its activation of target genes in fatty acid oxidative metabolism in the fetal and/or neonatal liver from the pregnant animals receiving clofibrate has not been determined in previous studies. In the current study, we examined both peroxisomal and mitochondrial $\beta$-oxidation using ${ }^{14} \mathrm{C}$-labeled long-chain fatty acids C18:1 and C24:0. Results from this study indeed demonstrated that maternal feeding of clofibrate increases hepatic fatty acid oxidation in the pig's liver at birth and $24 \mathrm{~h}$ after birth. The increase appears to be associated with the enhanced CPT I and ACO specific activities in the liver. The results achieved in the newborns exposed to clofibrate prenatally via the maternal diet were similar to the increase in vitro and vivo fatty acid oxidation reported in neonatal pigs receiving clofibrate directly postnatally $[10,13]$. Because the increase of CPT I specific activity was congruent with the great increase in mRNA expression, the stimulation of fatty acid oxidation in the liver, particularly in the mitochondria, resulted from the gene expression potentially due to the activation of PPAR $\alpha$ by clofibrate. In contrast with CPT I, however, the expressions 
of ACO and PPAR $\alpha$ mRNA were not significantly induced in clofibrate-exposed pigs. This suggests that other factors might be involved in the upregulation of ACO specific activity. Data from studies with rodent fetuses indicated that PPAR $\alpha$ mRNA expression is associated with the postpartum age and hormonal and/or nutritional status of the mother. The induction of liver PPAR $\alpha$ mRNA expression occurs around birth and the expression maintains an elevated level throughout the suckling period [32], while the content of peroxisomes and the activity of peroxisomal enzymes appear to occur in late fetal development and peak dramatically at birth [33]. These results imply that the ACO protein and PPAR $\alpha$ mRNA might have reached pinnacle expression at birth. Indeed, the increase in relative PPAR $\alpha$ mRNA was not observed in the liver from clofibrate fed rats in a study conducted by Ringseis et al. [34]. They suggested that endogenous free fatty acids might reduce the capability of fibrates to active PPAR $\alpha$, and consequently its metabolic effects, because ACO is the enzyme containing PPAR response element and responds to changes in polyunsaturated fatty acid levels in a PPAR $\alpha-$ dependent manner. Furthermore, a different physiological status, such as a fasting state, might provoke a different PPAR $\alpha$ response in the liver of fetuses. The induction of peroxisomal oxidation occurs immediately postpartum, is greater in the suckled versus fasted neonatal pigs, and is reliant on the initiation of suckling [35]. Thus, the lower response in mRNA expressions of ACO and PPAR $\alpha$ might be due to the developmental stage and the physiological status of the fetuses because the mRNA of PPAR $\alpha$ was also measured in a fasted state in this study.

The effect of the developmental ages of fetuses on oral food intake and gastrointestinal digestion has been described in humans and animals [36,37], but information on the energy metabolism in the fetus is very limited after delivery. Results from earlier studies showed that hepatocytes isolated from term guinea pigs were unable to oxidize fatty acids, but the capability was developed in the first $12 \mathrm{~h}$ after birth. The production of ${ }^{14} \mathrm{C}$ measured in $\mathrm{CO}_{2}$ and ASP from $1-{ }^{14} \mathrm{C}$ labeled fatty acids at $6 \mathrm{~h}$ was $40-50 \%$ of the production at $24 \mathrm{~h}$. At $12 \mathrm{~h}$ of age the rate of fatty acid oxidation had already reached the rate at $24 \mathrm{~h}$ and did not change during suckling in the first week of life. These data show that the capacity for $\beta$-oxidation and ketogenesis develops maximally in this species during the first 6-12 $\mathrm{h}$ after birth, and appears to be partly dependent on the development of fatty acid-activating enzymes [38]. Similarly, a low fatty oxidation rate with a high esterification was also observed in hepatocytes isolated from term fetal rabbits, whatever the octanoate concentration in the medium [39]. Consistent with the observations in term guinea pigs and rabbits, the fatty acid oxidation obtained in term pigs at the time of delivery by $\mathrm{C}$-section was also low even when compared with the rate measured in newborn pigs born naturally [5]. The low fatty acid rate was increased significantly in the first $24 \mathrm{~h}$, in which the rate was increased 2.3 fold in mitochondria and 1.9 fold in peroxisomes. However, the increase in mitochondria apparently was not due to an increase of the key enzyme CPT I activity. The activity measured at $24 \mathrm{~h}$ was not significantly different from the activity measured at $0 \mathrm{~h}$ after the delivery. A similar phenomenon was also observed in newborn and $24 \mathrm{~h}$ fasted pigs [5]. The increase might be associated with an increase in the number of mitochondria observed in neonatal pigs during in the first $12 \mathrm{~h}$ [40] and/or a decrease of sensitivity of CPT I to malonyl-CoA inhibition observed in 24-h-old pigs [5]. In contrast with mitochondria, the increase of fatty acid oxidation in peroxisomes was accompanied with a 2.3 fold increase of the ACO. Even so, it is notable that the oxidation rate of C24:0 was not significantly promoted during the first $24 \mathrm{~h}$ in peroxisomes, suggesting differences between mitochondria and peroxisomes in the capability of oxidizing fatty acids. Because the very long-chain fatty acid exclusively is activated in micorosomes or/ and peroxisomes, the low fatty acid oxidation might be associated with a low activity of very long-chain acylCoA synthetase. These results imply the impact of postpartum age on the metabolic pathway varied among subcellular compartments.

Peroxisomal fatty acid oxidation catalyzes chain-length shortening of monounsaturated fatty acid and saturated very long-chain fatty acid. Evidence indicated that C24:0 could only be oxidized initially in peroxisomes after activation by the acyl-CoA sythetase enzyme in endoplasmic reticulum and peroxisomes in brain and liver [41,42]. Peroxisomes at least have two enzyme systems for fatty acid activation: 1 for long-chain fatty acid and 2 for very-long-chain fatty acid [42]. Indeed, there was no substantial ${ }^{14} \mathrm{C}$ accumulation in either $\mathrm{CO}_{2}$ or ASP or both of $\mathrm{CO}_{2}$ and ASP from C24:0 in mitochondria. Neither clofibrate-exposure nor age had any influence on the definitely negligible mitochondrial ${ }^{14} \mathrm{C}$ accumulation from $\mathrm{C} 24: 0(\leq 1 \%)$. The percentage of C24:0 oxidation in peroxisomes was more than $80 \%$ of the total oxidation. Clofibrate had no effect on the relative oxidative capacity of peroxisomes although the efficacy of clofibrate was increased by postpartum age. This result suggests that the very long-chain fatty acid is catabolized exclusively in peroxisomes. In contrast with C24:0, high ${ }^{14} \mathrm{C}$ accumulations in $\mathrm{CO}_{2}$, ASP and $\mathrm{CO}_{2}+\mathrm{ASP}$ from $\mathrm{C} 18: 1$ were observed in both mitochondria and peroxisomes, suggesting that C18:1can be oxidized initially in both of the organelles. Similar results were observed also using C18:1 and erucic acid as substrates in our previously study [13]. 


\section{Conclusions}

In conclusion, clofibrate from maternal oral feeding during gestation is absorbed and hydrolyzed to clofibric acid, which can cross the porcine placenta and enter the fetal circulation system. Fetuses that were exposed to clofibric acid via maternal-placental transfer had a higher hepatic capacity to oxidize fatty acid at birth as compared to control fetuses. The high fatty acid oxidative capacity resulted from an increase in key enzyme activities induced by clofibric acid via activation of PPAR $\alpha$ and its target genes. The promoted fatty acid oxidation by activation of PPAR $\alpha$ and its target genes was attenuated in fasted newborns with postpartum age. Postpartum age also increased fatty acid oxidation. The increase was associated with development and was not influenced by clofibrate supplementation. Results from this study suggest that clofibrate could be examined as an agent to induce precocious development of ACO and possibly improve milk fat oxidation and pig survivability.

\section{Abbreviations \\ ACO: Acyl-CoA oxidase; ASP: Acid soluble products; CPT: Carnitine palmitoyltransferase; C18:1: Oleic acid; C24:0: Lignoceric acid; PPARa: Peroxisomal proliferator-activated receptor.}

\section{Competing interests}

This project was supported by National Research Initiative Competitive Grant no. 2007-35206-17897 from the USDA National Institute of Food and Agriculture and by the North Carolina Agriculture Research Service. The author(s) declare that they have no competing interests.

\section{Authors' contributions}

$\mathrm{XL}$ as the lead and corresponding author was in charge of designing and conducting the experiment. He also collected the samples, performed the biological measurements and completed the statistical analyses. SKJ was involved in sample collection and conducted the molecular analyses. JO was involved in experimental design, sample collection, data analysis and discussion. All authors read and approved the final manuscript.

\begin{abstract}
Authors' information
$\mathrm{XL}$ is a Research Associate Professor at the Department of Animal Science at NCSU. His main areas of research are neonatal survival and lipid metabolism primarily focused on the regulation of fatty acid oxidation during neonatal development and epigenetic regulation of fetal development and placenta growth. He is also interested in the role of polyunsaturated fatty acid in the development of intestine in neonates and the role of trace minerals and vitamins in the stressed animals. SKJ is a Senior Research Scientist at the Department of Animal Science at NCSU. Her main area of interest is identifying the molecular mechanisms of nutritional immunology associated with neonatal gastrointestinal health and development. She is interested in the fundamental question of how bioactive nutrients are involved in the developing gastrointestinal tract of the pig and using the pig as a model for infant nutrition. JO is a Williams Neal Reynolds Professor in the Department of Animal Science at NCSU, his research interests are molecular and metabolic regulation of lipid digestion and metabolism; neonatal nutrition; intestinal growth and metabolism in normal and pathophysiological states. His program is focused on using the young pigs as a model for the human infant in nutrition and digestive physiology. He also has teaching responsibilities in the areas of nutrition and biochemistry.
\end{abstract}

\section{Acknowledgements}

We thank Anthony Blikslager, DVM, PhD, DACVS for caesarean section of the sows, and staff at the North Carolina State University Swine Educational Unit, Raleigh for assistance of the animal management.
Received: 17 December 2014 Accepted: 10 March 2015

Published online: 26 March 2015

\section{References}

1. NAHMS. Swine 2006 Part III: Reference of Swine Health, Productivity, and General Management in the United States, 2006. 2006. (pdf 688kb 3/08). http://www.aphis.usda.gov.

2. Knauer MT, Hostetler CE. US swine industry productivity analysis, 2005 to 2010. J Swine Health Prod. 2013;21:248-52.

3. Girard J, Pégorier JP. An overview of early post-partum nutrition and metabolism. Biochem Soc Trans. 1998;26:69-74. Review.

4. Pégorier JP, Duée PH, Girard J, Peret J. Metabolic fate of non-esterified fatty acids in isolated hepatocytes from newborn and young pigs. Evidence for a limited capacity for oxidation and increased capacity for esterification. Biochem J. 1983;212:93-7.

5. Lin X, Shim K, Odle J. Carnitine palmitoyltransferase I control of acetogenesis, the major pathway of fatty acid \{beta\}-oxidation in liver of neonatal swine. Am J Physiol Regul Integr Comp Physiol. 2010;298:R1435-43.

6. Rakhshandehroo M, Knoch B, Müller M, Kersten S. Peroxisome proliferator-activated receptor alpha target genes. PPAR Res. 2010;2010:612089. doi:10.1155/2010/612089.

7. Brady PS, Marine KA, Brady LJ, Ramsay RR. Co-ordinate induction of hepatic mitochondrial and peroxisomal carnitine acyltransferase synthesis by diet and drugs. Biochem J. 1989;260:93-100.

8. König B, Kluge H, Haase K, Brandsch C, Stangl Gl, Eder K. Effects of clofibrate treatment in laying hens. Poult Sci. 2007;86:1187-95.

9. Litherland NB, Bionaz M, Wallace RL, Loor JJ, Drackley JK. Effects of the peroxisome proliferator-activated receptor-alpha agonists clofibrate and fish oil on hepatic fatty acid metabolism in weaned dairy calves. J Dairy Sci. 2010;93:2404-18.

10. Peffer PL, Lin X, Odle J. Hepatic beta-oxidation and carnitine palmitoyltransferase I in neonatal pigs after dietary treatments of clofibric acid, isoproterenol, and medium-chain triglycerides. Am J Physiol Regul Integr Comp Physiol. 2005;288:R1518-24.

11. Yu XX, Drackley JK, Odle J. Rates of mitochondrial and peroxisomal beta-oxidation of palmitate change during postnatal development and food deprivation in liver, kidney and heart of pigs. J Nutr. 1997;127:1814-21.

12. Cheon Y, Nara TY, Band MR, Beever JE, Wallig MA, et al. Induction of overlapping genes by fasting and a peroxisome proliferator in pigs: evidence of functional PPARalpha in nonproliferating species. Am J Physiol Regul Integr Comp Physiol. 2005;288:R1525-35.

13. Bai $X$, Lin X, Drayton J, Liu Y, Ji C, Odle J. Clofibrate increases long-chain fatty acid oxidation by neonatal pigs. J Nutr. 2014;144:1688-93.

14. Laclide-Drouin H, Masutti JP, Hatier R, Dauça M, Grignon G. Effect of clofibrate on the peroxisomes of the intestine of the rat during foetal development. Ital J Anat Embryol. 1995;1:411-7.

15. Wilson GN, King T, Argyle JC, Garcia RF. Maternal clofibrate administration amplifies fetal peroxisomes. Pediatr Res. 1991;29:256-62.

16. Simpson AE, Brammar WJ, Pratten MK, Cockcroft N, Elcombe CR. Placental transfer of the hypolipidemic drug, clofibrate, induces CYP4A expression in 18.5-day fetal rats. Drug Metab Dispos. 1996;24:547-54.

17. Ringseis R, Gutgesell A, Dathe C, Brandsch C, Eder K. Feeding oxidized fat during pregnancy up-regulates expression of PPARalpha-responsive genes in the liver of rat fetuses. Lipids Health Dis. 2007;6:6.

18. Herfel TM, Jacobi SK, Lin X, Fellner V, Walker DC, et al. Polydextrose enrichment of infant formula demonstrates prebiotic characteristics by altering intestinal microbiota, organic acid concentrations, and cytokine expression in suckling piglets. J Nutr. 2011;141:2139-45.

19. Gornall AG, Bardawill CJ, David MM. Determination of serum proteins by means of the biuret reaction. J Biol Chem. 1949;177:751-66.

20. Du L, Xu Y, Musson DG. Simultaneous determination of clofibrate and its active metabolite clofibric acid in human plasma by reversed-phase high-performance liquid chromatography with ultraviolet absorbance detection. J Chromatogr B Analyt Technol Biomed Life Sci. 2003;794:343-51.

21. Walusimbi-Kisitu M, Harrison EH. Fluorometric assay for rat liver peroxisomal fatty acyl-coenzyme A oxidase activity. J Lipid Res. 1983;24:1077-84.

22. Bremer J, Woldegiorgis G, Schalinske K, Shrago E. Carnitine palmitoyltransferase, activation by palmitoyl-CoA and inactivation by malonyl-CoA. Biochim Biophys Acta. 1985;833:9-16. 
23. Stefanini S, Mauriello A, Farrace MG, Cibelli A, Ceru MP. Proliferative response of foetal liver peroxisomes to clofibrate treatment of pregnant rats. A quantitative evaluation. Biol Cell. 1989;67:299-305.

24. Beck F. Comparative placental morphology and function. Environ Health Perspect. 1976;18:5-12

25. Ridderstråle Y, Persson E, Dantzer V Leiser R. Carbonic anhydrase activity in different placenta types: a comparative study of pig, horse, cow, mink, rat, and human. Microsc Res Tech. 1977:38:115-24

26. Cayen MN, Ferdinandi ES, Greselin E, Robinson WT, Dvornik D. Clofibrate and clofibric acid. Comparison of the metabolic disposition in rats and dogs. J Pharmacol. 1977;200:33-43.

27. Luci $\mathrm{S}$, Kluge H, Hirche F, Eder K. Clofibrate increases hepatic triiodothyronine (T3)- and thyroxine (T4)-glucuronosyltransferase activities and lowers plasma T3 and T4 concentrations in pigs. Drug Metab Dispos. 2006;34:1887-92

28. Luci S, Giemsa B, Hause G, Kluge H, Eder K. Clofibrate treatment in pigs: effects on parameters critical with respect to peroxisome proliferator-induced hepatocarcinogenesis in rodents. BMC Pharmacol. 2007;7:6. 2007. doi:10.1186/1471-2210-7-6.

29. Gonzalez FJ. Regulation of hepatocyte nuclear factor 4 alpha-mediated transcription. Drug Metab Pharmacokinet. 2008;23:2-7. Review.

30. Peters JM, Shah YM, Gonzalez FJ. The role of peroxisome proliferator-activated receptors in carcinogenesis and chemoprevention. Nat Rev Cancer. 2012:12:181-95

31. Sartori C, Stefanini S, Cimini A, Di Giulio A, Cerù MP. Liver peroxisomes in newborns from clofibrate-treated rats. II. A biochemical study of the recovery period. Biol Cell. 1992;74:315-24.

32. Panadero $M$, Bocos $C$, Herrera E. Relationship between lipoprotein lipase and peroxisome proliferator-activated receptor-alpha expression in rat liver during development. J Physiol Biochem. 2006;62:189-98.

33. Brun S, Carmona MC, Mampel T, Viñas O, Giralt M, et al. Uncoupling protein-3 gene expression in skeletal muscle during development is regulated by nutritional factors that alter circulating non-esterified fatty acids. FEBS Lett. 1999:453:205-9.

34. Ringseis R, Eder K. Influence of pharmacological PPARalpha activators on carnitine homeostasis in proliferating and non-proliferating species. Pharmacol Res. 2009:60:179-84.

35. Yu XX, Drackley JK, Odle J. Food deprivation changes peroxisomal beta-oxidation activity but not catalase activity during postnatal development in pig tissues. J Nutr. 1998;128:1114-21.

36. Buddington RK, Sangild PT, Hance B, Huang EY, Black DD. Prenatal gastrointestinal development in the pig and responses after preterm birth. J Anim Sci. 2012;4:290-8.

37. Rasch S, Sangild PT, Gregersen H, Schmidt M, Omari T, et al. The preterm piglet - a model in the study of oesophageal development in preterm neonates. Acta Paediatr. 2010;99:201-8.

38. Shipp DA, Parameswaran M, Arinze IJ. Development of fatty acid oxidation in neonatal guinea-pig liver. Biochem J. 1982:208:723-30.

39. Pégorier JP, Duée PH, Clouet P, Kohl C, Herbin C, et al. Octanoate metabolism in isolated hepatocytes and mitochondria from fetal, newborn and adult rabbit. Evidence for a high capacity for octanoate esterification in term fetal liver. Eur J Biochem. 1989;184:681-6.

40. Mersmann HJ, Goodman J, Houk JM, Anderson S. Studies on the biochemistry of mitochondria and cell morphology in the neonatal swine hepatocyte. J Cell Biol. 1972;53:335-47.

41. Bhushan A, Singh RP, Singh I. Characterization of rat brain microsomal acyl-coenzyme A ligases: different enzymes for the synthesis of palmitoyl-coenzyme A and lignoceroyl-coenzyme A. Arch Biochem Biophys. 1986:246:374-80

42. Wanders RJ, van Roermund CW, van Wijland MJ, Schutgens RB, Heikoop J, et al. Paroxysmal fatty acid beta-oxidation in relation to the accumulation of very long chain fatty acids in cultured skin fibroblasts from patients with Zellweger syndrome and other peroxisomal disorders. J Clin Invest. 1987:80:1778-83.

\section{Submit your next manuscript to BioMed Central and take full advantage of:}

- Convenient online submission

- Thorough peer review

- No space constraints or color figure charges

- Immediate publication on acceptance

- Inclusion in PubMed, CAS, Scopus and Google Scholar

- Research which is freely available for redistribution

Submit your manuscript at www.biomedcentral.com/submit 